\title{
Ethnologies
}

\section{Heritage Preservation : Museum Conservation and First Nations Perspectives}

\section{Miriam Clavir}

Volume 24, numéro 2, 2002

Musées

Museums

URI : https://id.erudit.org/iderudit/006638ar

DOI : https://doi.org/10.7202/006638ar

Aller au sommaire du numéro

Éditeur(s)

Association Canadienne d'Ethnologie et de Folklore

ISSN

1481-5974 (imprimé)

1708-0401 (numérique)

Découvrir la revue

Citer cet article

Clavir, M. (2002). Heritage Preservation : Museum Conservation and First

Nations Perspectives. Ethnologies, 24(2), 33-45. https://doi.org/10.7202/006638ar
Résumé de l'article

Cet article traite des définitions divergentes de la conservation du patrimoine qu'ont les conservateurs de musées et les membres des Premières Nations. Il explore ces différences au niveau de la méta-narration et dans les détails, en ciblant quelques problèmes liés à la conservation tels que " considère-t-on un objet endommagé » et « tous les objets devraient-ils être conservés ? ». De plus, les gens des Premières Nations cités dans cet article liaient la conservation aux pratiques muséales, aussi présentons-nous leurs opinions sur les musées et la pratique muséale. L'auteur tente également de savoir si l'emploi du terme " ethnographique " au sujet des collections autochtones reste approprié, de même que nous explorons le sous-domaine de la conservation de ces collections. Une grande partie de cet article est consacré aux points de vue des gens des Premières Nations, cités dans leurs propres termes.
Ce document est protégé par la loi sur le droit d'auteur. L'utilisation des services d’Érudit (y compris la reproduction) est assujettie à sa politique d'utilisation que vous pouvez consulter en ligne.

https://apropos.erudit.org/fr/usagers/politique-dutilisation/ 


\title{
Heritage Preservation: Museum Conservation and First Nations Perspectives
}

\author{
Miriam Clavir \\ Senior Conservator \\ University of British Columbia Museum of Anthropology \\ Vancouver
}

\begin{abstract}
The recent history of the museum field has sometimes been described as a shift in central focus from objects to audiences. Rather than existing primarily for the benefit of their collections, museums are increasingly understood as existing for the benefit of the communities that host and support them (Rounds 2001: 4).
\end{abstract}

Conservation became a professional field when museums "existed for the benefit of their collections." If one understands the phrase "benefits of the communities" to include the originators of the collections, which today most ethnographic museums in Canada and many internationally believe they should $\mathrm{do}^{1}$, then museum conservation is doubly challenged. Not only can the preservation of the collections be considered "old hat" within the competing claims for prioritization and funding of the diverse mandates of the contemporary museum, but the museum's stakeholders include groups with legitimate claims for unprecedented access to collections, and often with requests to borrow and use objects from the collections. Conservators traditionally view handling and use as posing potential risk to the physical integrity of the object. Professional museum standards and practices regarding preservation and access have been seen as being in conflict with First Nations needs and requests. This paper will focus on the differing definitions museum conservators and First Nations have of "heritage preservation."

1. The extent to which museums are actually working in partnership with First Nations communities in the conception and management of museum projects which benefit both the community and the museum is another matter. 


\section{"Ethnographic": An Appropriate Term?}

I would like first to consider another key definition. The word "ethnographic" was used above to describe collections from aboriginal peoples; it is also the term used for the subspecialty of conservation that preserves these collections in museums. The term "ethnographic," however, originally came from an era which largely reflected the power imbalance of colonialism, and in which western scholars believed they had "the unquestioned mandate to intrude into the lives of nonEuropeans" in a one-sided activity designed to "describe, interpret, and represent the lives of people in other cultures" to the West (Barrett 1996: 151). "Ethnographic" comes from a time when many museum exhibits displayed the objects collected in dramatic dioramas illustrating a romanticized traditional lifestyle and bearing no relationship to the existing community or to how the people viewed their history. "Ethnographic" is certainly a term which is not used very often by indigenous peoples. Is it still appropriate to use this term today, when museums have shifted so substantially in the direction of working with aboriginal communities so that projects are planned and accomplished in partnership?

There is, however, a contemporary meaning of the word "ethnographic," current at least in North American anthropology. In simple terms it means "talking to people;" it describes a methodology. To be sure, in the past the term "ethnographic" was also used for fieldwork methods, but it occurred, especially in the early days of anthropology, within the paradigm of a university/museum investigator and subjects being studied, and the inherent power imbalance in this one-sided situation. While many anthropologists have since participated as partners with the communities they work in, it remains true nonetheless that the staff, such as the conservation staff, of the museums housing the field collections were still most often divorced from the people who actually "provided" the objects.

Today "ethnographic" fieldwork is used to mean an exchange of knowledge, with the terms negotiated by both parties, and which will result in benefits for both parties. Ethnographic field methods are now being used in disciplines other than anthropology, such as nursing and education; they are being used by "us" to gain greater reflexivity about our own institutions and practices. "Ethnographic" has come to mean "working with people" in the most productive sense of a partnership, and it may in fact be the best word we could use to describe a 
contemporary vision of, for example, the conservation practice in museums which house and preserve the material culture of indigenous peoples. The emphasis for ethnographic conservators today should be on working with people as well as objects.

\section{“Heritage Preservation": What does it Mean?}

Differing perspectives on preservation are succinctly summed up by a young First Nations woman, Kim Lawson:

All the potlatch stuff that you're given is special because it's from a potlatch, so that means you should use it more. But the English and Danish side of the family, if something's special, then you take care of it better. You put it aside. It makes it more special when you use it less. This is a generalization, of course (Lawson as quoted in Clavir 2002: 114).

Chief Ken Harris said,

We don't really conserve - in the same sense as storage at the Museum of Anthropology - we renew. It's a continuity, like a lineage (Harris (Gitxsan) as quoted in Clavir 2002: 114).

Although the quotations above and the ones throughout the rest of this paper are from First Nations individuals of diverse ages, with different family backgrounds, life experiences, different ties to traditional practices, from different communities, and other dissimilarities, almost everyone I talked to supported a concept of preserving heritage through active participation in it. "Renew" is an active verb in Harris' statement. There remains, though, a fundamental contradiction for museum conservators if they are asked to conserve ethnographic collections while at the same time supporting First Nations requests to borrow objects for use.

Within Western culture, heritage is often described materially, in terms of a cultural product or production, mediated by an organization, and accessed through a relatively passive act such as viewing an exhibit. Within First Nations cultures, heritage is often described culturally, as Harris has done above. Heritage is described in terms of a participatory on-going "process" rather than a "product." Museum conservation involves using physical and intellectual means to ensure that material fragments from the past do not disappear. The First Nations people I talked to favoured a concept of heritage preservation involving continuing and/or renewing past traditions and their associated material 
culture; that is, preserving the culture's past by being actively engaged in it and thereby ensuring that it has a living future.

\section{Preserving the Physical, Preserving the Cultural}

Do museums have any value? Yes, according to Sandy Jones, a Salish elder. He would like a museum in his community and he would go and see what he used to wear, and show it to his grandson. His grandson will learn his culture from the longhouse, though, from his own participation in traditional spiritual life - from participating rather than seeing objects in a museum (in Clavir 2002: 127).

Peggy Svanvik:

My son has a mask in the museum that's been used three times in potlatches, and it's become more valuable. It has more value now. Each time it's used it becomes more valuable (Svanvik, 'Namgis (Kwakwaka $\left.{ }^{\prime} w a k w\right)$ as quoted in Clavir 2002: 133).

Rita Barnes:

The fact of the objects being used, I think, that's important. And understanding the use of it. Taking my granddaughter to the potlatches (Barnes (Kwakwaka'wakw) as quoted in Clavir 2002: 137).

It is the cultural meanings attached to the object that are significant for First Nations. (Museum conservators preserve the physical object and its integrity as a source of knowledge). It is not surprising that preserving the "intangibles" associated with material culture is of great concern to First Nations, whereas the conservators' specialty is preservation of the tangible material. The following quotations show further that the many aspects of what is social or cultural, and the associated intangibles that are experienced, or related to the tangible cultural materials, are very important.

Peggy Svanvik:

At the museum, there was a whole bunch of young people who came in. They didn't speak the Kwakwala language, but what they really wanted to know from Mrs. Cranmer was "Who was my family?" What were the names of my family? What were the crests, what can I use when I'm making my own dance regalia? For these young people, it was really important to them to know who they were, and where they come from. It hadn't been before. Now they wanted to know. For their self-esteem, they need to know (Svanvik as quoted in Clavir 2002: 127). 


\section{Gloria Cranmer Webster:}

Well I don't know if museum people should really be talking about preservation or maintenance of culture because all you've got are things and those things... really don't mean much by themselves, sitting on shelves. They only come to life when they are really used. So, I guess, your [conservator's] job is to preserve those "things." It's our job to preserve the culture that those "things" have meaning in (Gloria Cranmer Webster, 'Namgis (Kwakwaka'wakw), founder and former director of the U'mista Cultural Centre, as quoted in Clavir 2002: 161).

Although the social and cultural elements are the most important aspects to preserve, this does not mean that preserving objects is unimportant.

\section{Rita Barnes:}

When you think back on how much we lost in such a short period, and then feeling even back then that we didn't have a choice, that it was taken away from us... when you think in terms of how much we lost in such a short period, and we now see that we can save and maybe retrieve, then of course we should try to preserve as much as we can (Barnes as quoted in Clavir 2002: 131).

\section{Debra Sparrow:}

They're old and they came from time, and I think they just verified existence; they verified what was so that we understand what is, so we can go forward with what will be (Sparrow (Salish) as quoted in Clavir 2002: 123).

Preserving physical objects was considered by many of the First Nations people as having its place and value, but cultural concerns in most cases would take precedence.

\section{Rita Barnes:}

I keep telling myself, I have to tell him [her nephew, Beau Dick, a well-known carver] that maybe he should replicate it so that [the original] can be preserved for as long as possible. So when I was telling my brother this, he said, "Well, for what purpose? You know, it will just stay in the museum forever." And I said, "I hope so." And he said, "But why? When it can be used?" I said, "Sure it can be used," I said, "Beau can make another one exactly like it." And he said, "You're probably right, but you see it's never..." My brother is quite a bit older than I am, and he said, "It just doesn't make sense to me to have 
thesethings in a museum when they can be utilized for the things that we do today." And that was a literal translation for how we refer to having potlatches. [She speaks in Kwakwala] "X́an's 'wigilasex" they always said. And it just simply means, "For what we do" (Barnes as quoted in Clavir 2002: 127).

If preserving objects as part of preserving heritage is indeed important, however, what about the concept of allowing certain objects, such as totem poles, to deteriorate, to "complete their natural cycle?" It would be necessary to ask the community in each case, but the following were some of the opinions expressed by the First Nations people I talked to.

Peggy Svanvik (speaking about the memorial poles at the Alert Bay graveyard):

We often get comments like - I have a niece who worked in the tourist bureau [and she] has said that the tourists have come and said, "You people ought to be ashamed of yourselves for not keeping up these poles." So I said maybe you need to tell those people that those poles aren't there as tourist attractions. They weren't put up there for tourists, they were put up there as memorial poles; that those memorial poles will stand there until they crumble, and when they crumble then gone are the memories. The old people say that they're not supposed to be maintained (Svanvik as quoted in Clavir 2002: 153).

\section{Adelynne Claxton:}

To see our baskets or swoqualth blankets on the verge of "total destruction" [they] should be given the "right to die." They have served their purpose, new ones would have to be made if our ancestors had so desired (Claxton (Salish) published in Clavir 2002: 153).

Some First Nations people, however, expressed mixed feelings about letting objects deteriorate even though doing so might be according to custom.

Ken Harris:

For sentimental reasons I would keep a particular mask but in the olden days they wouldn't. We used to burn our dead. And we also have a burning ceremony of these things once we've renewed them (Harris as quoted in Clavir 2002: 154).

\section{Debra Sparrow:}

Well, you know, I can understand them saying it [i.e., some objects should be allowed to deteriorate], but I also don't agree to the extent 
that some things, as we said before, need to be validated. But if we can have a pole that came from a century or two ago that still exists, there's strength in that deterioration as it happens. And whether we've slowed that process down, I mean, heavens, we're looking to slowing down our own deterioration every day! You know, we're putting on face cream, we're trying special remedies and potions to keep us younger, but when we meet an elder, you know, what do we feel in that? That we... hope we're as graceful as that when we're that age. And I think that that's just something that my boy needs to see, the old carvings. He needs to see [them]... he loves the museum (Sparrow as quoted in Clavir 2002: 154).

When asked whether she felt there were any objects that shouldn't be preserved, Gloria Cranmer Webster replied:

Not only for me but, I think, for a lot of Native people - we've had to change [our ideas with regard to] the way that objects are used. You know that traditionally when something wore out, somebody replaced it. When a pole fell down, that was the end of it. You didn't replace [re-erect] it. It had served its purpose. But I think that because of contact with museums and conservators and people like that, everyone began to look at things in a different way. You know, there's a totem pole by Willie Seaweed. We know there's never going to be another one by Willie Seaweed - and maybe for us it's not right - that we allow it to fall down and rot away. And I think people have developed a different way of looking at those objects and, as I said, I think it has to do with the way that we now know something about museums and conservation. And history (Cranmer Webster as quoted in Clavir 2002: 156).

At one cultural centre, a staff person stated that she felt that today people would prefer to see the poles preserved, and she noted several old poles that had been restored and given to local museums. Unlike the poles in the graveyard at Alert Bay, however, none of these were memorial poles currently in use. The Haisla Nation is in the process of repatriating a pole from Sweden. The Haisla are being asked by Sweden to house the pole in a building that has environmental controls. The Haisla have decided, therefore, to have two new poles carved: one to go back to Sweden as part of this exchange, and one to be erected on the site of the original pole. The latter will be allowed to deteriorate over time.

If objects are going to be kept, however, rather than be allowed to deteriorate, and still may be used and experience wear and tear, what then defines concepts of deterioration or damage for the First Nations people I talked to? 


\section{Gloria Cranmer Webster:}

Oh well, a Hamat'sa mask - if there's a scratch on it, it's part of being used. If it were damaged to the point where the beak wouldn't open or close, well, THAT'S damage! I think that anything that impairs the function - if the eyes won't open and close any more. Yes. But I think things like a little scratch or a feather coming loose or whatever is part of normal use (Cranmer Webster as quoted in Clavir 2002: 150).

John Moses, a conservator:

On a very practical level, damage to me would include tears, rips, split seams, pieces completely detached or missing altogether. It does not include flaking paint or shedding fur, worn fabric surfaces, creases, or use/wear marks in and of themselves. Damage is to be avoided in the first place, as far as is reasonably possible, and within the limits of an object's intended use within its originating community (Moses (Six Nations of the Grand River) as quoted in Clavir 2002: 151).

Webster and Moses (both of whom have worked extensively with collections), acknowledge that damage to the object is to be expected within the context of its social function. The object is considered damaged when its function, not its material, is impaired. The degree of seriousness of damage was also defined in social terms:

[Miriam Clavir]: And I guess if something happened during the dance [e.g., a piece falling off], I guess that would be very serious.

[Peggy Svanvik:] That would be very serious, especially for the dancer. And the dancer's family (Svanvik as quoted in Clavir 2002: 151).

\section{Gloria Cranmer Webster:}

The family giving the potlatch would have to give more money away to wipe away the shame of the accident (Cranmer Webster as quoted in Clavir 2002: 151).

Once again, the importance of the social or cultural attributes associated with or represented by material culture were emphasized.

\section{First Nations Perspectives, Conservation Perspectives}

From a professional museum point of view, preservation and access are often considered to be opposites. The people I spoke to rejected this "either/or" model and conceived of heritage preservation instead 
in a "both/and" framework. Rangi Te Kanawa (a conservator in New Zealand of Maori heritage) talked about bringing together different perspectives:

We have to educate our people and, in the same respect, the museum world has to be educated. The community out there, the people believe that their carving or their cloak is inside that museum and no one's ever going to see it. No one's ever going to touch it or be around it. It's never going to be worn. It's like it's never ever going to be loved in their eyes. And yet, in our [conservation] world, it's comfortable, it's lying flat, there's no dust on it. We're all together at the start, we both care a lot for our taonga [treasures], and now we just need to compromise (Te Kanawa (Ngati Maniopoto) as quoted in Clavir 2002: 231).

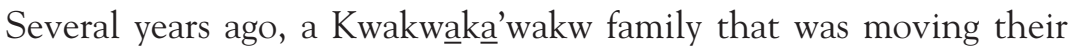
old regalia from the Kwagiulth Museum in Cape Mudge, B.C., to the U'mista Cultural Center in Alert Bay gave a potlatch for this event. The objects were central to the celebration, and normally regalia would be worn and danced at a potlatch. The family, however, chose to show the fragile old pieces but not to dance them. Out of respect for this ancestral regalia, it was, as tradition demanded, witnessed by those at the event, but handled by its First Nations owners according to museum conservation standards (including the desire for white gloves). It was conserved while still being culturally feasted.

As Rangi Te Kanawa concluded in one of her statements: "It's actually the same amount of respect for both" (Te Kanawa as quoted in Clavir 2002: 243).

\section{First Nations Perspectives, Conservation Perspectives, Museum Perspectives}

Much of the preceding discussion has been a comparison of First Nations and museum conservation viewpoints. In my individual conversations, however, it became evident that people felt that conservation could not be disassociated from the context in which it was practised. Conservators and other museum professionals may see conservation as a separate profession within the museum culture, but the First Nations people expressed their opinions on conservation as part of the whole of museum practice and history. The following quotations illustrate a range of perspectives about museums. 


\section{Don Bain:}

When these pieces came to the museums, they were sold to the museum by families, sold to collectors who in turn donated it, or sold it to the museums. Some pieces were stolen out from graves or families, individuals, but when they came to the museum does that mean that in the grand scheme of things, that's where they were meant to be? You know, that their perceived end is at a museum? Or is that just part of their life? I don't know. I think that objects within the museum are still, well, they're unsettled, and that the communities, for the most part, they don't know exactly what's out there yet. The issues are unsettled, and the status of the objects are yet to be determined (Bain (Lheit-lit'en - Carrier) as quoted in Clavir 2002: 208).

\section{Debra Sparrow:}

I think we are really excited to know that the museum is there, and the changes with museums in being more open, in opening their doors. Also to know that these particular people whose objects are housed in the museum are a functioning people. They're not people whose past only lives in a museum, they're still here in the future (Sparrow as quoted in Clavir 2002: 208).

\section{Adelynne Claxton}

Museums have come a long way in this day and age, they are now more lenient, they will loan out to the community a sacred object to be used for special ceremonies. I think it is about time (Claxton as published in Clavir 2002: 209).

\section{Leona M. Sparrow:}

They've changed somewhat. But the attitude is still there, although the actions are not always the same. The attitude is attempt to control - attempt control of the objects, rather than look at the museum as being a facility for protecting the object so that people can access and use it, OK. It's protect at all costs rather than protect for use (Sparrow (Salish) as quoted in Clavir 2002: 209).

\section{Gloria Cranmer Webster:}

I think that there are a lot of changes happening in museums. A lot of museums are acquiring the kind of humility they should have had a long time ago. I think it finally got to people that there was this attitude in museums: "These things belong to us. We know everything and we don't have to ask anybody." That's changing now. Native people's attitudes towards museums are changing as well. There are 
more Native people working in museums. That makes a difference (Cranmer Webster as quoted in Clavir 2002: 209).

\section{Debra Sparrow:}

And that's what I'm willing to do. I'm willing to look at what we can do now - you and me. I know what went wrong. I know what was. But I just want to work... about always being positive, about how we can work together now (Sparrow as quoted in Clavir 2002: 211).

\section{Dena Klashinsky:}

Conservators should have an awareness of community values. Sometimes, cultural values may be in conflict with what action you have to take. However, it's important to at least recognize, to acknowledge, those cultural values and community concerns. At times, you may have to make different or difficult decisions, but I think such acknowledgment is important. I think people appreciate that, even if the steps taken are not as they would have originally hoped, at least there's an awareness of their values and concerns, an acknowledgment of them. If that kind of dialogue takes place, and there is a real connection and mutual respect, then a community may be willing to trust in the process (Klashinsky (Kwakwaka'wakw and Salish) as quoted in Clavir 2002: 211).

\section{Dolly Watts:}

What I would like to see is cooperation with the people. If they're not coming forward, go out and tell them what's there and that repatriation is possible. Just bring the people up to date. They don't know. And that's so important, just to inform us. After all, we have a stake in the objects in the museum (Watts (Gitxsan) as quoted in Clavir 2002: 211).

\section{Howard Grant:}

Stronger communication. I would say to any museum or to any institute that as part of the curriculum they should visit First Nations communities, to talk, as you are doing right now... and to maintain posts, linkages, in respect to communicating with the public that someone owns the art pieces. Because too often we make academic decisions that are very logical and very real and albeit the right one, but people get offended. Almost all the right decisions are so debatable and so controversial, you know? And my thoughts are, this should have been done twenty years ago and not for a thesis paper but just general care of the object (Grant (Salish) as quoted in Clavir 2002: 212). 
Leona M. Sparrow:

And I'm not saying that the First Nations communities know everything, OK? I'm saying there is a spectrum of knowledge that each party has that has to be shared, and it has to be received in the right manner, and the educators have to realize that they don't know everything and respect that someone else may have knowledge that would be helpful (Sparrow as quoted in Clavir 2002: 212).

\section{Conclusion}

This paper has explored several aspects of the meaning of heritage preservation to First Nations people, and how this meaning differs from the perspective of museum conservation. In my discussion with various First Nations individuals about these and other questions related to heritage preservation, people emphasized the paramount importance of cultural protocols and concerns (the object's "conceptual integrity," as conservators might say). They also emphasized that preserving physical objects was important too, including preservation in museums or cultural centers, as appropriate to their communities' needs and norms. To accomplish museum conservation, however, or indeed other museum mandates involving the material culture of First Nations, people repeatedly emphasized the need to prioritize cultural concerns, and to establish better communication between museums and First Nations. The onus is on the museum to be proactive in working with the communities from which their collections originated.

Leona M. Sparrow:

Developing the communication lines, OK? Coming to a community, working with a community, rather than the community having to go bang on the door (Sparrow as quoted in Clavir 2002: 209).

As Dena Klashinsky says above,

If that kind of dialogue takes place, and there is a real connection and mutual respect, then a community may be willing to trust in the process (Klashinsky as quoted in Clavir 2002: 211). 


\section{References}

Barrett, Stanley R. 2000. Anthropology: A Student's Guide to Theory and Method. Toronto: University of Toronto Press.

Clavir, Miriam. 2002. Preserving What is Valued: Museums, Conservation and First Nations. Vancouver: UBC Press.

Rounds, Jay. 2001. "The Object in View: Rethinking the Relationship between Conservation and Exhibition". Exhibitionist 20 (2): 4-5. 